Journal of World Architecture

Research Article

\title{
Technical Analysis of Green Construction Management of Large Public Buildings
}

Bosong $\mathrm{Yi}$

Xi'an Aeronautical University, Xi'an 710077, China

Abstract: With the development of the times and the improvement of the economic level, the people's ideological consciousness has gradually changed, driven by the scientific concept of development and the concept of sustainable development, the people have been able to realize that, traditionally, the extensive economic model has led to more serious damage to the environment, and caused a certain degree of resource waste, but also endangered human health. As a result, the concept of healthy living has received more and more widespread attention. The construction industry as an important pillar of China's economic development, but also the implementation of the concept of sustainable development in China is one of the key points for the implementation of green construction of large public buildings, it is necessary to strengthen the management of technology, so in this paper, will be the main green construction of large public buildings management technology analysis work.

Keywords: Large public buildings; Green construction; Management techniques

Publication date: September, 2020

Publication online: 30 September, 2020

*Corresponding author: Bosong Yi,yibosong555@, 163.com

According to the current situation, the majority of construction units in China choose to reduce noise pollution and reduce environmental pollution in the way of green construction to meet the requirements of the various, but in fact, there are some construction units for the green construction management concept has not yet been completely clear, which also leads to the official launch of the construction work process is not able to scientific, reasonable, standardized and effective construction technology and Management measures are implemented. Thus, the construction unit is required to be able to actively establish and improve the standard green construction management program, and implement it in all aspects of construction, so as to effectively and efficiently achieve green construction ${ }^{[1]}$.

\section{Green construction management techniq- ues}

A good understanding of green construction management techniques is necessary if they are to be applied effectively and efficiently. In general, green construction management techniques can be divided into two main areas.

\subsection{Green construction management techniques}

To carry out green construction management for large public buildings, that is, in the process of construction of the project, the basic requirements for the full implementation, but also need to actively strengthen the implementation of the effect, in order to promote the implementation of green construction management technology to achieve the goal, the basic requirements and objectives are shown in Table 1 below.

Table 1. Key elements of green construction management techniques

\begin{tabular}{cl}
\hline \multicolumn{1}{c}{ Project } & \multicolumn{1}{c}{ Project Content } \\
\hline Basic requirements & $\begin{array}{l}\text { 1. Effective guarantee of the basic } \\
\text { requirements for safety and quality of } \\
\text { construction. } \\
\text { 2. Application of advanced construction } \\
\text { technology } \\
\text { 3. Implementation of scientifically sound } \\
\text { management programmes }\end{array}$ \\
& $\begin{array}{l}\text { 1. Savings in resources } \\
\text { 2. Reduce the level of environmental } \\
\text { pollution }\end{array}$ \\
3. Reduce construction costs
\end{tabular}

1.2 Significance of green construction management techniques 
The implementation of green construction concept, which can be fully embodied in the concept of sustainable development, and adhere to the construction rules of environmental protection first, through the application of appropriate technologies and processes, to promote the utilization of the resources has been significantly improved, so as to be able to low energy consumption, high efficiency, green and environmentally friendly advanced development concepts for effective application, not only to promote the economic benefits of construction enterprises. It is also able to realize the improvement of social benefits. In other words, the full application of green construction technology, not only to achieve the practical development of modern construction technology, but also to the construction of a harmonious ecological environment, and to achieve harmony between man and nature, effectively and efficiently promote the sustainable development of China $^{[2]}$. In general, the significance of the application of green construction management technology among large public buildings lies in the following aspects.

\subsection{Protection of the ecological environment}

Although the good development of the construction industry can effectively promote China's economic development, but at the same time, China's ecological environment has been damaged, and in the construction industry competition is becoming increasingly fierce, some construction enterprises in the pursuit of interests and put the protection of the ecological environment in disregard. The application of green construction technology, to a certain extent for the construction industry to implement screening work, thus contributing to the purification of the construction market, but also to strengthen the attention of construction enterprises for environmental protection work, can effectively reduce environmental pollution and achieve the protection of the ecological environment ${ }^{[3]}$.

\section{Conservation of resources}

Among the total energy consumption of social production in China, the energy consumption of the construction industry occupies about $40 \%$, which shows the huge consumption of energy in the construction industry. However, on the whole, China's energy resources have been in a relatively scarce state, thus, the energy-saving construction industry is worthy of attention. In the construction industry, the application of green construction technology, can promote the building construction process of energy consumption has been reduced, so as to save a large number of energy resources, not only to promote the quality of the building has been improved, but also for the construction industry to lay a solid foundation for the implementation of the concept of sustainable development.Second, the development status of green construction management technology

Green construction management technology applied in the past part of the construction management technology is summarized and deepened, for example, some units in the process of carrying out construction work, will generally choose to use the appropriate technology to promote the reduction of noise and pollution levels, in fact, it belongs to the green construction technology. But according to the current situation, the majority of construction units are not able to proactively apply green construction technology, and even part of the construction units on the application of green construction technology in a passive state, at the same time, the majority of construction units for green construction technology is not able to have an accurate, scientific understanding, which further leads to the implementation of green construction technology has been restricted. At the same time, most of the construction units for green construction technology is not able to have an accurate, scientific understanding, which further leads to the implementation of green construction technology is limited. And, China does not have a green construction technology can be replaced by a scientific method, it is difficult to effectively achieve resource conservation and environmental protection ${ }^{[4]}$.

\section{The specific application of green construct- ion management techniques}

For the construction industry, the most capable of embodying the concept of sustainable development, is the application of green construction management technology in large public buildings. So next, this paper will take the construction of a large shopping mall as a case study for the application of green construction management technology in large public buildings to explore the situation.

\subsection{Project Overview}

The mall is located in the center of a city with convenient transportation and a large number of residents around. The overall height of the building is 50 meters and is divided into 20 floors above ground and 3 underground floors, with the first floor being a pedestrian street, the second floor being an underground shopping mall and the third floor being a parking lot, with a total area of 55,210 square meters. 
In the construction work carried out in the mall, in order to avoid as far as possible to produce environmental damage, the surrounding residents of normal work and life interference and construction costs too high adverse effects, according to the actual situation of the construction site analysis, in the construction process, the most suitable application of management methods for dynamic management, and in the construction preparation stage and the official construction phase, are required to carry out the corresponding supervision and management work.

\subsection{The application of green construction manage- ment techniques}

The application of green construction management technology in practice, there are many matters that need attention, from an overall point of view, it can be divided into three main parts, in order to promote the effectiveness of the application of green construction management technology can be enhanced ${ }^{[5]}$.

\subsubsection{Engineering design work}

In the design process of the overall layout of the mall, in

order to be able to effectively meet the functional needs of the building as a whole, it is necessary to ensure that it can be fully compatible with the actual situation of the construction site ${ }^{[6]}$. Therefore, not only need to conduct a careful and comprehensive analysis, but also need to pay attention to the building can have on the surrounding environment, as well as the surrounding environment can have on the various aspects of the building, so as to avoid architectural style and the surrounding environment incompatible and other undesirable situation $^{[7]}$.

\subsubsection{Active innovation of technology}

In the process of carrying out construction, if the application of traditional construction techniques, it is bound to lead to a certain degree of environmental pollution and damage, and also the normal work and life of the surrounding residents have a negative impact, this situation is seriously inconsistent with the concept of green construction management work, so it is necessary according to the actual situation of the mall, the technology for positive innovation, in order to promote construction methods to Be effectively improved, and application of technologies

\begin{tabular}{|c|c|}
\hline Actual situation in the mall & Innovative applications of technology \\
\hline 1. Relatively large footprint & 1. Apply BIM technology to the construction. \\
\hline 2. which is more versatile & 2. digital modeling to understand and grasp the construction \\
\hline 3. All aspects of piping and wiring are very complex. & situation in a timely, comprehensive and clear way \\
\hline $\begin{array}{l}\text { 4. The various types of pipelines and lines collide, cross and influence } \\
\text { each other. }\end{array}$ & $\begin{array}{l}\text { 3. Make the pipeline line get scientific and reasonable } \\
\text { arrangement }\end{array}$ \\
\hline 5. Obstacles to the smooth progress of construction & 4. If there are adverse conditions, they can be detected and \\
\hline 6. large amount of work & adjusted in a timely manner. \\
\hline
\end{tabular}

Table 3. Pollution analysis

\begin{tabular}{|c|c|c|}
\hline Type of contamination & Dust contamination & Water pollution \\
\hline Cause of occurrence & $\begin{array}{l}\text { 1. Earthmoving } \\
\text { 2. Earthmoving } \\
\text { 3. failure to provide timely and proper cover for accumulated } \\
\text { earthwork }\end{array}$ & $\begin{array}{l}\text { 1. Waste water from the construction process } \\
\text { 2. Rainwater harvesting }\end{array}$ \\
\hline Adverse effects & $\begin{array}{l}\text { 1. Dust phenomena } \\
\text { 2. Dust pollution } \\
\text { 3. Polluting the surrounding environment }\end{array}$ & $\begin{array}{l}\text { 1. Air pollution } \\
\text { 2. Polluting water resources } \\
\text { 3. Affects the health of personnel }\end{array}$ \\
\hline Governance measures & $\begin{array}{l}\text { 1. In the process of transportation of soil and construction } \\
\text { materials, should try to use closed transport measures, while } \\
\text { for soil and construction materials, should be scientifically } \\
\text { reasonable cover, to avoid leakage or scattered situations } \\
\text { 2. The earth, sand and cement and other granular building } \\
\text { materials or dusty building materials, in the storage, should } \\
\text { focus on the use of closed, or after a good stacking, the use of } \\
\text { the corresponding cover treatment } \\
\text { 3. In the construction site around, should be set up to dust belt, } \\
\text { in order to avoid the dust pollution involved in the expanding } \\
\text { range, but also more conducive to promote the construction } \\
\text { safety to be guaranteed }\end{array}$ & $\begin{array}{l}\text { 1. Adopt scientific and reasonable measures for } \\
\text { corresponding treatment } \\
\text { 2. Test the quality of the treated sewage water. } \\
\text { 3. If the water quality can fully comply with the } \\
\text { national sewage discharge standard, it can be } \\
\text { discharged. } \\
\text { 4. If the sewage contains difficult to treat oil } \\
\text { or toxic substances, etc., it must be used for } \\
\text { water resistance, good sealing performance of } \\
\text { the container, after the unified recycling and } \\
\text { treatment, sewage leakage is strictly prohibited. }\end{array}$ \\
\hline
\end{tabular}


help to promote the construction quality and efficiency, but also help to reduce construction costs ${ }^{[8]}$. It should be noted that, because of the need to apply a large number of transport equipment, so the transport process should be promptly cleaned of the garbage generated in order to avoid environmental pollution. See Table 2.

\subsubsection{Preventing pollution}

Pollution can be divided into two forms of dust pollution and water pollution, both of which can produce certain adverse effects, so it is necessary to analyze and summarize their specific conditions and governance measures, as shown in Table 3.

According to the above it can be understood that in the process of carrying out the construction work of large public buildings, the application of green construction management technology in which is conducive to more effective energy saving, material saving, water saving, land saving, so as to effectively implement the protection of the environment, not only can strengthen China's experience in the application of green construction management technology, but also can further promote the construction industry in China to get healthy and sustainable development.

\section{References}

[1] Feng PC, Li JX. Implementation of green construction in passive housing projects of public buildings[J]. Value Engineering,2019, 38(2): 167-170.

[2] Liu XG. Green energy saving and environmental protection measures in the construction of industrial and civil buildings[J]. Construction Engineering Technology and Design, 2018(14): 5311.

[3] Lv SC.Research on the application of BIM technology in green public building design[J]. Commodity and Quality, 2017(37): 26.

[4] Sun W. Curriculum system reform of civil engineering based on BIM technology[J]. Henan Building Materials, 2020(5): 132133.

[5] Huang JZ. About the excellent planning and management of the second phase B site project of Xiamen Strait Exchange Center[J]. China New Technology and New Products, 2019(13): 126-127.

[6] Liao LF, Yang JY, Hu GZ. Application of green construction in large public buildings - the case of "Tian Yuan Place" in Wuyi New District, Fujian Province[J]. Engineering Technology Research, 2019, 4(4): 8-9.

[7] Yu HQ. Research on the application of green construction technology in high-rise building construction[J]. Green Environmental Building Materials, 2018.

[8] Cao Y. Methods of innovative building construction management under the concept of green construction management[J]. Construction Engineering Technology and Design, 2018(16): 1668 . 